\title{
A New Twist to a Chronic HCV Infection: Occult Hepatitis C
}

\author{
Bashar M. Attar ${ }^{1,2}$ and David Van Thiel ${ }^{3}$ \\ ${ }^{1}$ Division of Gastroenterology and Hepatology, Cook County Health and Hospitals System, 1901 West Harrison Street, \\ Chicago, IL 60612, USA \\ ${ }^{2}$ Rush University Medical Center, Chicago, IL 60612, USA \\ ${ }^{3}$ Advanced Liver and Gastrointestinal Disease Center, Berwyn, IL 60402, USA
}

Correspondence should be addressed to Bashar M. Attar; battar@rush.edu

Received 23 November 2014; Revised 15 April 2015; Accepted 24 May 2015

Academic Editor: Tatsuya Toyokawa

Copyright (C) 2015 B. M. Attar and D. Van Thiel. This is an open access article distributed under the Creative Commons Attribution License, which permits unrestricted use, distribution, and reproduction in any medium, provided the original work is properly cited.

Background. The prevalence of occult hepatitis C infection (OCI) in the population of HCV-RNA negative but anti-HCV positive individuals is presently unknown. OCI may be responsible for clinically overt recurrent disease following an apparent sustained viral response (SVR) weeks to years later. Purpose. To review the available current literature regarding OCI, prevalence, pathogenic mechanisms, clinical characteristics, and future directions. Data Sources. Searching MEDLINE, article references, and national and international meeting abstracts for the diagnosis of OCI (1990-2014). Data Synthesis. The long-term followup of individuals with an OCI suggests that the infection can be transient with the loss of detectable HCV-RNA in PPBMCs after 12-18 months or alternatively exist intermittently and potentially long term. The ultimate outcome of HCV infection is decided by interplay between host immune responses, antiviral therapies, and the various well-identified viral evasion mechanisms as well as the presence of $\mathrm{HCV}$ infection within extrahepatic tissues. Conclusion. The currently widely held assumption of a HCV-cure in individuals having had "SVR" after 8-12 weeks of a course of DAA therapy as recently defined may not be entirely valid. Careful longitudinal followup utilizing highly sensitive assays and unique approaches to viral isolation are needed.

\section{Background}

The last 3 decades have been phenomenal progress in the recognition, replication mechanisms, and treatment of $\mathrm{HCV}$ (Box 1).

These advances have enabled the treatment of chronic hepatitis $\mathrm{C}$ infections to undergo dramatic changes since the inception of therapy with interferon $\alpha 3$ times/week for 48 weeks in 1991-1992 [1, 2]. Not only have the rates of a sustained viral response (SVR) increased to values approximately $90 \%$, but the duration of therapy has been reduced from 48 weeks to 6-12 weeks with the currently utilized protocols consisting of orally administered direct acting antiviral (DAA) agents [3-5]. Most relapses following historical treatment protocols as well as current protocols occur within 1-4 weeks after the end of treatment (EOT) time point. Yet, a minority of relapses occur months to years later [6-8]. Although the origin of these late relapses is uncertain, an increasing amount of data suggests that they may represent activation of an occult hepatitis C virus infection (OCI) [9-13]. OCI was first reported by Pham et al. [9] in anti-HCV positive patients recovered after a self-limited (untreated) episode of hepatitis $\mathrm{C}$ and in individuals with SVR due to interferon (IFN) treatment who had normal liver enzyme [9]. In the same year, Castillo et al. [10] described HCV-RNA presence in anti-HCV negative patients with elevated liver enzymes. Therefore, these authors discovered OCI and recognized the two different forms of this occult infection [10] (Table 1). The prevalence of OCI in the population of HCV-RNA negative but anti-HCV positive individuals is presently unknown but has stimulated considerable interest [12, 13]. Currently, the detection of HCV-RNA in liver tissue or in peripheral blood mononuclear cells (PBMCs) occurring in an individual with undetectable HCV-RNA in serum represents the gold-standard for the identification of an occult $\mathrm{HCV}$ infection. The definition of an OCI has been expanded by the identification of HCV-RNA in extra hepatic tissues of anti-HCV negative individuals [9-13]. Currently, OCI 
1975: recognition of non-A, non-B hepatitis (HCV) as a specific entity,

1989: HCV specifically identified,

1991-1992: initial approval and use of interferon (IFN) therapy for HCV,

1993: HCV genome organization and polyprotein processing defined,

1996: first three-dimensional structure of HCV protein, the NS3-4A protease,

1997: first infectious clone of HCV isolated,

1998: ribavirin added to interferon therapy,

1999: replicon system developed enabling in vitro study of the virus replication,

2003: development of functional HCV pseudoparticles,

2003: initial proof-of-concept of HCV replication utilizing a protease inhibitor,

2004: first reports of occult HCV infection (OCI),

2005: recombinant infectious HCV produced in tissue culture,

2009: IL28B polymorphisms identified that affect viral responses to therapy,

2011: approval of the first direct acting antivirals (DAA) agents,

2013: complete HCV life cycle defined in humanized mice,

2013: all oral therapy utilizing DAA approved.

Box 1: Major developments in HCV identification, replication mechanisms, life cycle sequence, and treatment.

TABLE 1: Characteristics of occult hepatitis C infection (OCI $)^{+}$.

\begin{tabular}{lcc}
\hline & $\begin{array}{c}\text { Secondary } \\
\text { OCI* }\end{array}$ & $\begin{array}{c}\text { Cryptogenic } \\
\text { OCI }\end{array}$ \\
\hline $\begin{array}{l}\text { Evidence of liver injury } \\
\text { ALT elevated }\end{array}$ & No & Yes \\
$\begin{array}{l}\text { Histological lesions } \\
\text { Inflammatory: minimal to mod. }\end{array}$ & Occasional & Frequent \\
$\quad$ Fibrotic: minimal to severe & Frequent & Frequent \\
Organs involved & Yes & Yes \\
Liver & Yes & Yes \\
Lymphatic system (PBMC) & Positive & Negative** \\
Anti-HCV detection & & \\
HCV-RNA detection & Yes & Yes \\
Serum & Yes & Yes \\
PBMC & Yes & Yes \\
Liver & At least 9 & Unknown \\
Longevity of persistence & years & \\
\hline
\end{tabular}

${ }^{*}$ Secondary OCI: residual infection continuing after spontaneous resolution or after achieving apparent SVR following HCV therapy.

${ }^{* *}$ Antibodies against HCV can be detected in up to $40 \%$ in cryptogenic OCI.

${ }^{+}$Adopted from Pham et al. [19], Liver International, 2010; 502-11.

is characterized by undetectable levels of HCV-RNA in serum/plasma utilizing current laboratory assays with the identification of HCV-RNA in PBMCs and/or liver tissue utilizing molecular assays and analyte treatment protocols resulting in enhanced sensitivity [9-15]. A major limitation of identifying OCI cases is the lack of standardized universal sensitive method for detecting HCV-RNA in these studies. Thus, the detection rates of $\mathrm{HCV}$-RNA in PBMCs have varied from $0 \%$ to $50 \%$ [16-19]. Using a less sensitive assay to detect HCV-RNA, Carreño et al. [16] found that 6 of 12 individuals have detectable genomic HCV-RNA (50\%) in PBMCs. These authors used a quantitative, strand-specific, real-time reverse transcription polymerase chain reaction (RT-PCR) to detect genomic and antigenomic strands. The total RNA concentration from PBMCs and hepatic tissue was determined by utilizing spectrophotometry [16]. In contrast, Bernardin et al. [17] used a highly sensitive transcriptionmediated amplification (TMA) test performed in duplicate assays. None of their 69 aviremic individuals with hepatitis $\mathrm{C}$ infection had a detectable PBMC-associated HCV-RNA. The HCV-RNA detection rates in liver biopsy specimens varied widely among studies ranging from $0 \%$ to $83 \%$ [2023]. Haydon et al. other studies detected HCV-RNA in liver biopsy tissues in 10 of 12 individuals (83\%) using RT-PCR [20]. Barrett et al. showed that none of the 33 serum PCRnegative women for HCV had a HCV in their hepatic tissue specimens using a sensitive nested PCR with an internal control [21]. Using RT-PCR, Sugiyasu et al. [22] differentiated $\mathrm{HCV}$ infected individuals who did not develop chronic hepatitis $\mathrm{C}(\mathrm{CHC})$ and cleared the HCV virus spontaneously and their hepatic tissue specimens were negative for HCVRNA from those who developed CHC. Of those who did not develop CHC, 6 of 6 individuals who cleared the HCV-RNA spontaneously were found to have negative PCR testing of HCV in their hepatic tissue by using specific RT-seminested PCR which was described by Tomimatsu et al. [23]. In contrast, of the two individuals who developed $\mathrm{CHC}$ in their report and experienced a SVR with interferon-based therapy, one had persistent HCV genome in the liver [22].

There are only a few studies which applied high stringency methods for HCV-RNA detection and calibrated their assays as well as utilization of sequence analysis or nucleic acid hybridization probe amplification [24-34]. Pham et al. [27] reported the original finding of occult hepatitis $\mathrm{C}$ infection (OCI) subsequently used these highly sensitive assays such as the hybridization to support their findings with assays capable of detecting HCV-RNA to $\leq 10 \mathrm{vge} / \mathrm{mL}(\leq 3 \mathrm{IU} / \mathrm{mL})$ or $\leq 5 \mathrm{vge} / \mathrm{ug}(\leq 1.5 \mathrm{IU} / \mathrm{ug})[26,28]$. Despite what is believed to be a cure and a complete eradication of HCV-RNA either spontaneously or after therapy, low levels of HCVRNA persisted in plasma (100-200) virus genome equivalent 
(vge) or genome copies/mL, or up to $100 \mathrm{vge} / \mathrm{ug}$ total viral RNA in both PBMCs and hepatic tissue specimens [27-30]. Furthermore, it was shown that individuals with OCI who have CHC have both a unique cytokine pattern as well as a gene expression pattern which differs from those who do not manifest an OCI $[24,31]$.

Others have utilized ex vivo stimulation of PBMCs with mitogens to identify the cause of OCI defined as the presence of HCV-RNA positive and negative strands and HCV proteins $[9,25,27,35]$. To further improve the detection of OCI, screen serial samples collected from the same individuals at different periods $[25,27,31]$. The quality and the amount HCV-RNA recovered of HCV-RNA is crucial to the identification of the viral RNA and require specific handling of the specimens [36].

Importantly, the detection of low levels HCV-RNA in serum following an apparent "SVR" has been implicated in HCV infectivity by MacParland et al. [37] who reported exposure of human normal T cells to trace HCV levels found in plasma and supernatants from cultured PBMCs obtained from these individuals with apparent SVR post-Peg-IFN/ RBV therapy for periods as long as 72 months could establish a de novo $\mathrm{HCV}$ infection with replication of $\mathrm{HCV}$ virions in vitro. Only 20-50 copies of HCV were sufficient to produce infection of these human T cells [37]. Similarly, Katayama et al. have shown that 20 copies of HCV-RNA prepared by dilution of serum collected during the pre-acute phase of hepatitis $\mathrm{C}$ of an infected chimpanzee can result in an infection in inoculated chimpanzees without an increase in ALT levels [38].

Despite studies supporting the evidence of presence of OCI, there continues to be a controversy by some authors who challenged the existence of OCI [17, 39-43].

\section{Clinical Characteristics of OCI}

The use of highly sensitive assays and procedures that enrich $\mathrm{HCV}$ in test samples by amplifying the viral RNA present in the analyte material obtained from plasma, PBMCs, liver tissue, or other tissue sites such as the thyroid, salivary glands, pancreas, kidney, and even the brain, where HCV-RNA has been shown to exist, defines OCI [12-15, 44, 45]. Importantly, HCV-RNA replication manifested by the presence of the negative strand of HCV-RNA has been reported in some of these extrahepatic sites [44, 46] including PBMCs [9]. The implications of these findings are clinically and critically important. Thus, the use of the terms "cure" and "total eradication" of HCV following treatment occurring in association with a currently defined SVR may not be appropriate at least in a minority of cases.

The observation that HCV can infect extra-hepatic tissues in addition to the liver particularly PBMCs and other tissues which represent privileged reservoirs for $\mathrm{HCV}$ that are potentially responsible for the development of an OCI has reinvigorated the interest in $\mathrm{HCV}$ replication. The continued replication of genomic $\mathrm{HCV}$ in these extrahepatic tissue sites at a rate well below that which occurs in the liver during active infection at a time when HCV-RNA is undetectable in the serum most probably is the origin of OCI [16, 32, 47-52].
There are currently two immune-viral/clinical distinct forms of OCI both of which were originally reported by Pham et al. [9] and Castillo et al. [10]:

(1) Individuals with detectable HCV-RNA and anti$\mathrm{HCV}$, in the absence of elevated liver enzymes, which occurs in otherwise successful antiviral therapy or a self-limiting episode of hepatitis $\mathrm{C}$. These individuals have HCV-RNA detected in their serum, PBMCs, and liver. And have been labeled as having "secondary OCI" indicating the presence of residual HCV infection persisting despite spontaneous resolution of hepatitis C or achieving apparent "SVR" following HCV therapy [9].

(2) Individuals presenting with HCV-RNA positivity but anti-HCV negative with elevated liver enzymes [10].

The diagnosis of these OCI in anti-HCV positive individuals with normal liver enzymes was originally based on investigations of PBMC and plasma but not liver biopsies. Subsequently, hepatic tissues were investigated in these cases by Pham et al. 6-66 months after HCV therapy $[9,50]$ and by Radkowski et al. 41-98 months following HCV treatment [28].

\section{HCV OCI Experience}

Although it is not particularly surprising to detect $\mathrm{HCV}$ using highly sensitive amplifying assays for HCV-RNA, Chen at al. reported the detection of $\mathrm{HCV}$ and continued viral replication during ongoing antiviral treatment of patients with PegIFN/R at a time when viral RNA was undetectable in the serum. These data help to explain the late reappearance of detectable HCV-RNA by currently available clinical tests in individuals having had an apparent SVR in as many as $11.6 \%$ of the studied cases [46].

Specifically, a total of 122 patients, suspected of having an occult HCV infection following a putative SVR, were studied utilizing the detection of anti HCV core and methods to detect HCV-RNA either in the liver or PBMC [53]. Anti-HCV core protein was detected in the serum and PBMCs in $36 \%$ of the cases. After ultracentrifugation of the serum, 70/122 (57\%) were reported to have identifiable HCV-RNA in their serum and 74/122 (61\%) had HCV-RNA identifiable in their PBMCs. When these two approaches for the detection of OCI were combined, $91 \%$ of the patients (111/122) were positive in at least one of the two assays. In light of these results, occult HCV infection was reported to be present in as many as $91 \%$ of patients, who are anti-HCV positive and have had a SVR defined as having no HCV-RNA detected in their serum utilizing currently available commercial assay methods [53].

These data strongly suggest that occult HCV infection may be present in at least some individuals who either spontaneously or after antiviral treatment have "cleared" virus from their serum [54-56].

Ansaldi et al. [57] reanalyzed the data of Castillo et al., [14] who reported a prevalence of $2.7 \%$ anti-HCV positive individuals among the Italian population and determined that the likelihood of a false negative result for anti-HCV was 
essentially zero. In a study reported by de Marco et al., [11] the prevalence of OCI infection in "healthy" Italian population was $3.3 \%$ of individuals who were $\mathrm{HCV}-\mathrm{Ab}$ negative and serum HCV-RNA negative and had detectable HCV-RNA in their PBMCs. Although the number of participants in this study was relatively small with only $3.3 \%$ being positive for HCV-RNA among a total of 276 subjects, it supports the existence of OCI not only in anti-HCV positive individuals but also those who are anti-HCV negative. Moreover, this finding suggests that HCV infection might be spread from an apparent "healthy" individual with an OCI to an HCV naive individual who may subsequently develop clinical disease [45]. These latter observations are consistent with the observation that despite multiple approaches to reduce the risk of leukocyte-transfusion-related HCV infection, to include leukocyte depletion, the efficacy of such procedures at reducing the already low risk of virus transmission with blood product transfusion continues to occur albeit rarely $[45,57,58]$.

De Marco et al. [59] evaluated the prevalence of OCI in a larger cohort (314) of infectious liver disease-free (ILDF) subjects having no clinical evidence for HBV, HCV, CMV, $\mathrm{EBV}$, and other viral illness, who were followed to determine the natural history of OCI. The prevalence of OCI in the ILDF subjects studied was $1.27 \%$, while an even higher prevalence of OCI (28\%) was identified in HBV carriers. No specific $\mathrm{HCV}$ genotype has predominated in the subjects with OCI studied to date [59].

The long-term followup of individuals with an OCI suggests that the infection can be transient with the loss of detectable HCV-RNA in PPBMCs after 12-18 months or alternatively exist intermittently and potentially long term [59]. Confirmation of these studies with a longer follow-up period is needed to define the clinical characteristics and prevalence of OCI, the rate of OCI resolution, and/or the rate of reactivation either as intermittent OCI or overt clinical infection. These data of Barril et al. [60] of intermittent OCI are consistent with the data of Castillo et al., [61] who reported a series of 37 cases having an OCI manifested by abnormal liver enzymes for a minimum of 12 months with the persistence of very low levels of HCV-RNA intermittently in PBMCs and serum in the subjects they followed for a mean of 55.7 months.

Studies with 10 years of followup after achieving an apparent SVR have reported the presence of small amounts of HCV-RNA in individuals' serum or plasma, PBMCs, and/or hepatic tissue associated with normal liver enzymes indicating the presence of OCI by several authors [9, 28$30,62,63$ ] with a range of $10-100 \%$ depending mostly on the sensitivity of the methods utilized to detect HCV-RNA [19]. Despite significant improvement in liver histology after achieving a SVR, minimal to mild disease activity associated with focal hepatic necrosis, lymphocytic infiltration, and various stages of fibrosis have been reported [28, 30, 50].

Taken together, these studies suggest that the currently widely held assumption of a HCV-cure in individuals having had "SVR" after 8-12 weeks of a course of DAA therapy as recently defined may not be entirely valid. Careful longitudinal followup utilizing highly sensitive assays and unique approaches to viral isolation are needed to define the frequency of both OCI and a true SVR in individuals receiving these shorter courses of therapy.

\section{OCI in Immune Impaired Individuals}

In similar but not identical studies, Barril and colleagues [60] reported prevalence of an OCI in 45\% of 109 hemodialysis patients. These investigators also reported on the potential for transmission of HCV by individuals with OCI. Specifically, they found that the presence of OCI among the relatives of individuals they studied was comparable to that found among family members of patients with overt HCV infection. The Barril et al. report [60] and others [64, 65] however stand in contrast to that of other authors $[39,66]$ who were not able to identify cases of OCI in different cohorts of immune-suppressed subjects consisting of 28 oncohematological patients [67] and 26 kidney-transplant recipients [68].

An intriguing additional question is what is the relationship between the existence of an OCI and the subsequent development of either a lymphoproliferative disease [69] or cryoglobulinemia [70, 71]? Youssef et al. [72] investigated the occurrence of OCI in Egyptian patients with variety of lymphoproliferative disorders (LPDs) (Figure 1). Their study included 100 subjects consisting of 50 consecutive cases with a newly diagnosed lymphoproliferative disease and 50 healthy anti-HCV negative controls. 13 of the 50 (26\%) with an LPD group were positive for anti-HCV and all were HCV-RNA positive as well. HCV-RNA was detected in PBMC in 18 of the 50 LPD patients (36\%). Importantly, ten of these 18 cases were negative for both anti-HCV and HCV-RNA in their serum and therefore represented true cases of OCI. In the healthy anti-HCV negative controls, the $\mathrm{HCV}$-positive (genomic) strand was found in PBMC in 2 (4\%) of those studies thereby fulfilling the criteria for an OCI. The HCV genotype in all 12 cases of OCI was genotype 4, the predominant genotype present in Egypt [72].

Farahani et al. [73] identified OCI in 2 (1.9\%) of 104 Iranian patients with LPD. The authors suggested testing for genomic HCV-RNA in PBMCs in the absence of liver biopsy in individuals with LPD [73].

Similarly, genomic and antigenomic HCV-RNA was detected in the PBMCs of 5 of 9 (56\%) individuals who had chronic hepatitis $\mathrm{C}$ with mixed cryoglobulinemia and achieved SVR after receiving antiviral therapy [71].

Castillo et al. [74] reported that occult HCV-RNA (detectable viral RNA in peripheral blood mononuclear cells or in serum after ultracentrifugation) was found in 34 of 87 patients with immune mediated glomerulonephritis versus 1 of 26 control patients with hereditary glomerulonephritis (Figure 2). Importantly, all of the cases studied were HCVRNA negative in serum utilizing a commercially available assay [75]. A multivariate analysis demonstrated a significantly increased risk of occult HCV in patients with immune mediated glomerulonephritis versus the controls with heritable forms of glomerulonephritis (odds ratio of 13.29). Furthermore, the rate of progression to end-stage renal disease tended to be faster in the OCI group of patients as compared to those without an OCI [74]. 


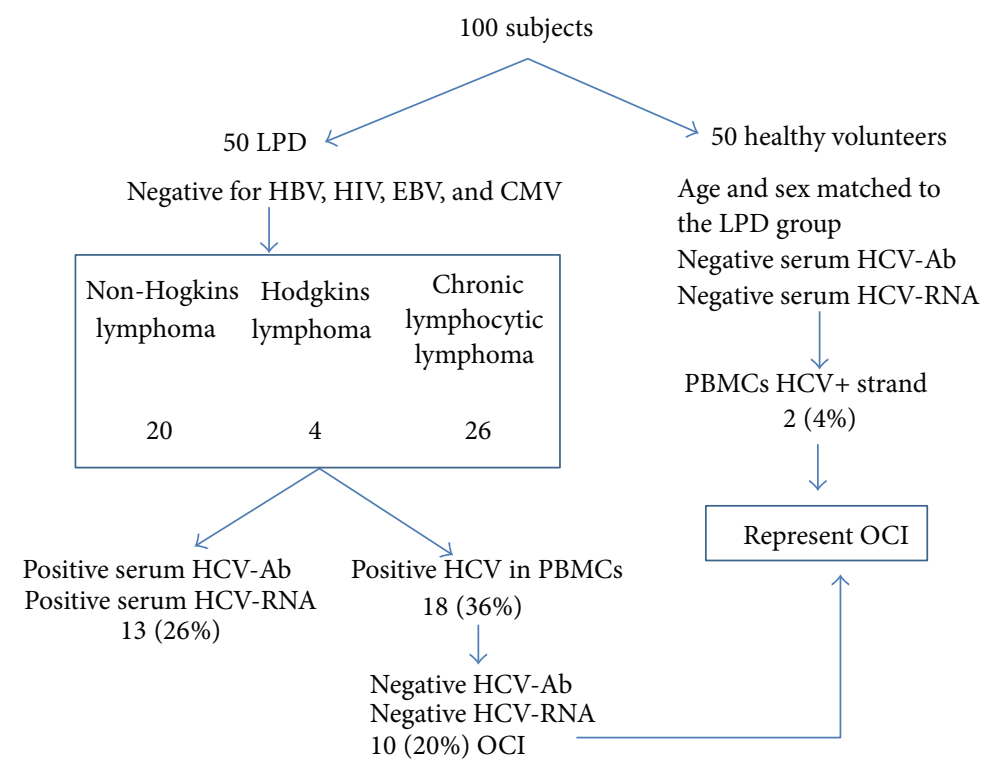

FIGURE 1: Prevalence of OCI in patients with chronic lymphoproliferative disorders (LPD). OCI was detected in $20 \%$ of the LPD group versus $4 \%$ in controls, adapted from [103].

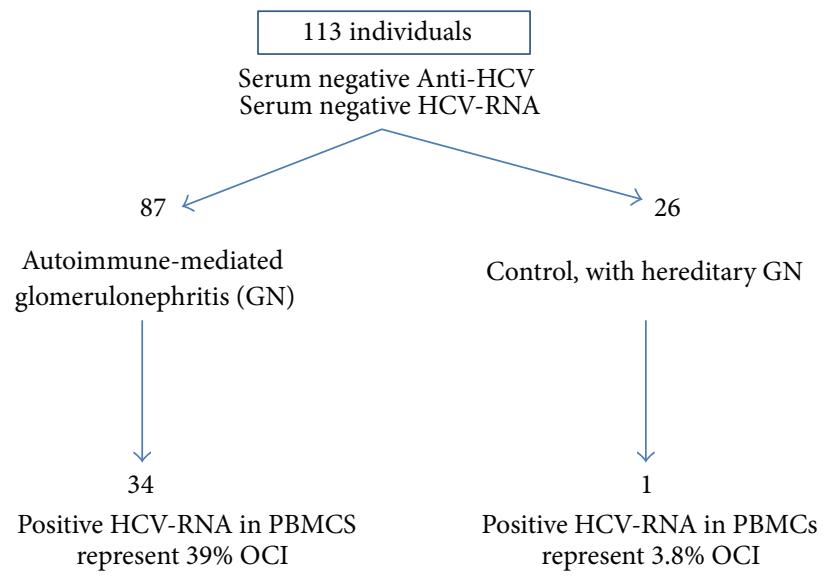

FIGURE 2: The prevalence of OCI in patients with primary and secondary glomerular nephropathies. There is a significant increased risk (odd ratio 13.29) of OCI in patients with immune mediated glomerulonephritis versus the controls [74].

Importantly, among patients with LPD, Kisiel et al. [76] studied 77 anti-HCV negative patients in Poland. HCV-RNA was detected by RT-PCR in $13 \%$ of the plasma samples, in $16.9 \%$ of the PBMCs samples, and in the bone marrow of $28.6 \%$ of the cases [76].

\section{Potential Pathogenic Mechanisms Resulting in an OCI (Box 2)}

Pham et al. [25] identified the subsets of immune cells involved in the HCV infection in individuals with $\mathrm{CHC}$ and others with OCI. They isolated immune cell subtypes from 7 patients with $\mathrm{CHC}$ and 7 individuals with occult infection and analyzed them for HCV-RNA. While HCVRNA occurred at a similar frequency in all of the various cell subtypes of individuals with $\mathrm{CHC}$, monocytes had the greatest viral load. In contrast, B cells in individuals with OCI manifested a tendency toward having higher HCV quantities compared to monocytes. The detection of $\mathrm{HCV}$ nonstructural protein $5 \mathrm{~A}$ and $\mathrm{HCV}$ variants that were not found in plasma defined HCV replication in different immune cell types which presumably serve as reservoirs of the virus in individuals with OCI [25].

Chen et al. [46] have reported that mononuclear cells, including T lymphocytes, are targets for HCV and these cells are reservoirs of replicating HCV regardless of the presence or absence of either symptomatic or asymptomatic infection. As these cells are readily accessible, they can be utilized to evaluate the status of extra hepatic HCV replication during an active infection during the course of antiviral treatment and after the apparent development of a putative SVR. In this context, the detection of HCV positive cells and in some cases the replicative negative viral strand in PBMCs confirms 
(I) Host defined mechanisms [16, 24, 25, 89, 98]:

(a) a host immune response characterized by a reduced Th- 1 and enhanced Th- 2 response to HCV,

(b) presence of host IL28B polymorphisms that are associated with a reduced response to IFN,

(c) host resistance to the therapeutic actions of ribavirin,

(d) HCV infection of B cells that manifest an interferon resistant phenotype,

(e) enhanced frequency of posttreatment OCI in cirrhotic individuals.

(II) Viral determined mechanisms [46, 79, 94]:

(a) viral mutations/quasispecies that enable infection of nonhepatic tissues (E2 polymorphisms and others),

(b) presence of viral quasispecies with a reduced replicative potential that are sequestered into nonhepatic tissues as a means of survival in the presence of "more fit" highly replicative species.

Box 2: Potential pathogenic pathways to an OCI.

the role of these cells as a HCV reservoir both during ongoing antiviral treatment and most importantly after its completion and thereby enabling the identification of cases of OCI [46].

The ultimate outcome of HCV infection is decided by interplay between host immune responses, antiviral therapies, and the various well-identified viral evasion mechanisms as well as the presence of $\mathrm{HCV}$ infection within extrahepatic tissues (reservoirs of occult infection) [77-81].

Quiroga et al. [77] showed that a strong and sustained $\mathrm{HCV}$-specific CD4+ and CD8+ T cell responses are essential for the resolution of $\mathrm{HCV}$ infection. Importantly, the authors [77] have considered these specific $\mathrm{T}$ cell responses as immune markers for predicting prior $\mathrm{HCV}$ exposure, recovery, or OCI. Depletion of CD4+ T cells plays a major role in the persistence of $\mathrm{HCV}$ infection while depletion of CD8+ T cells was associated with delayed clearance of HCV-RNA [82, 83]. Specifically, CD8+ T cell responses recognize viral antigens in the context of HLA class I, primed during acute HCV infection and considered to be critical for subsequent viral clearance [84]. In individuals, who have high levels of viral replication, the lack of viral control can be attributed to the development of viral mutations which potentially result in an enhanced viral infection of extra hepatic tissues that have a reduced rate of viral replication, cell surface expression of viral antigens, and subsequent recognition and elimination by $\mathrm{CD} 8+$ antiviral responses. Such mutational escape mechanisms have been shown to occur in a predictable fashion in the context of specific HLA profiles and are highly likely to play an important role in the persistence of HCV infection to include cases of OCI [80, 8486].

The cytokine balance between Th1/Th2 may also be a factor in the development of OCI cases [77, 84-89]. Mousa et al. [87] investigated the role of cytokine profiles including cytokines related to $\mathrm{T}$-cell immunoregulation in the development of OCI. They compared the cytokines responses between OCI and those with an identifiable chronic hepatitis $\mathrm{C}$ infection (CHC). They found that Th1 cytokines are significantly greater in cases of $\mathrm{CHC}$ patients than in those with OCI or control noninfected individuals. In contrast, individuals with an OCI had higher serum interleukin- (IL-) 4 and levels than did those with $\mathrm{CHC}$ and the healthy controls. Serum levels of IL-10 were higher in both OCI and $\mathrm{CHC}$ groups compared with control. Thus, the presence of a cytokine shift towards enhanced Th2 expression in OCI cases may have resulted in decreased serum level of IFN$\gamma$ and IL-2 cytokines associated with subsequently immune clearance of the viral infection [77, 84, 86-88]. Importantly, the maintenance of polyfunctional HCV-specific Th1 T cells, $\mathrm{CD} 4+$, and CD8+ memory $\mathrm{T}$ cells resulted in spontaneous clearance of $\mathrm{HCV}$ and better outcome of treatment of the HCV infection [88]. Pham et al. [24] reported that PBMCs from OCI individuals have higher levels of IFN- $\alpha$, IFN- $\gamma$, and TNF- $\alpha$ but less IL-10 than CHC patients. Stronger HCV replication in immune cells was noted in individuals with lower transcription of IFN- $\alpha$, IFN- $\gamma$, and TNF- $\alpha$, but higher levels of IL-10. These data support the presence of distinct cytokine pattern between OCI and CHC.

Plasma interferon-gamma-inducible protein-10 (IP-10) levels have been shown to be associated with early but not sustained virological response during treatment of acute and chronic HCV infection. Baseline IP-10 has been associated with viral levels but not treatment outcome. Individuals with high baseline IP-10 greater than 600 pg/mL rarely clear virus [90].

Several investigators have shown that HCV-infected subjects can harbor HCV quasispecies in their PBMCs that are not detectable in plasma. In such cases, it is presumed that the virus quasispecies identified in plasma is more efficiently replicative and as a result has created less space for the less actively replicating virus in plasma such that they become sequestered in nonhepatic reservoirs for virus [28, 32, 4649]. A potential additional explanation for these differences in the distribution of viral quasispecies may be related to the presence of viral mutations that confer a unique cellular tropism for PBMCs [91-95]. Specifically, studies of the hypervariable $\mathrm{E} 2$ region of $\mathrm{HCV}$ have shown that viruses with specific mutations in this region are found more frequently in B lymphocytes and monocytes than in the serum $[46,79]$. This suggests that the identification of HCV species with E2 polymorphisms is likely enriched in PBMC as compared to plasma and liver tissue as may represent a unique pathogenic basis for the development of a subsequent OCI. These viral variants can be found before and during antiviral therapy and may persist well in these extrahepatic sites long after a presumed SVR has been achieved.

The IL28B gene locus encodes for IFN- $\kappa 3$, a member of type III IFN family [44, 96-98]. Type III IFN family shares 


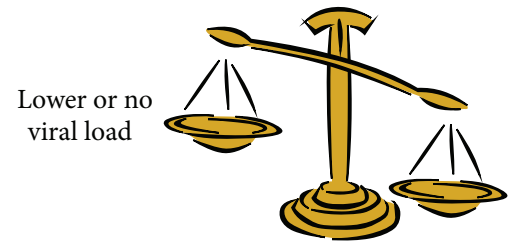

Viral clearance "SVR"
Abundant antigen-specific cellular response to virus

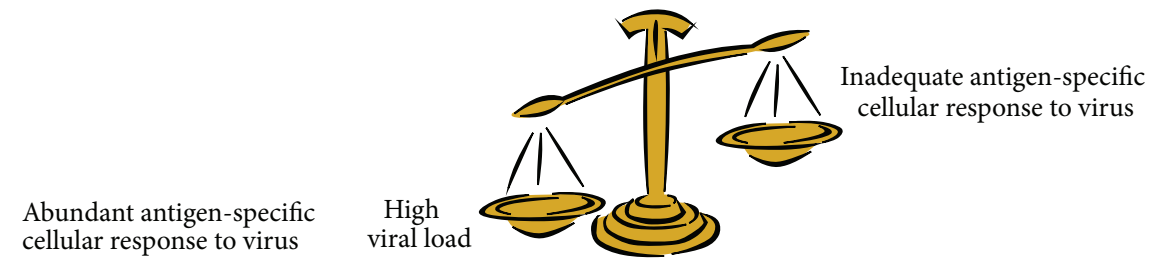

Viral persistence or chronic viremia

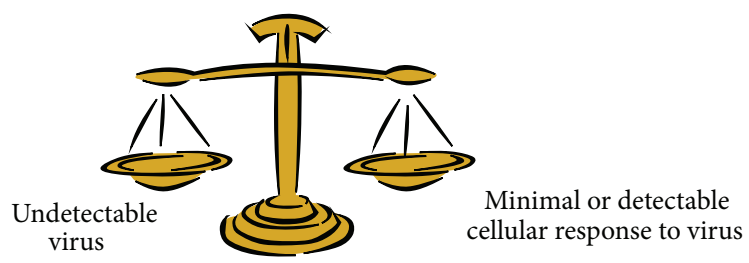

Occult hepatitis C infection (OCI)

FIGURE 3: Balanced immunologic response to virus.

downstream signaling pathways with type I IFNs. Both interferons initiate Jak/signal transduction and subsequent activation of transcription (STAT), and the subsequent intracellular pathways that upregulate the transcription of IFN-stimulated genes (ISGs), resulting in an enhanced antiviral response. Recently, several large genome-wide association studies have identified several single nucleotide polymorphisms (SNPs) linked to interferon lambda 3 (IFN $\lambda 3$ ) that are associated with either a high likelihood of viral clearance with IFN treatment or the spontaneous resolution of $\mathrm{HCV}$ infection. These observations generated intense research activity and strongly supported the identification of IFN $\lambda 3$ genetic variants which serve as important predictive biomarkers of IFN treatment of HCV [99-101].

Specifically these studies have demonstrated that the presence of a single nucleotide polymorphism (SNP) at the IL28B locus, specifically the presence of the $\mathrm{T}$ alleles of rs12979860 or the G alleles of rs8099917 is associated with a reduced response to PegIFN/RBV therapy and importantly also an increased prevalence of PBMC infection (OR: 3.564; 95\% CI: 1.114-11.40, $P=0.0437$ ) [98, 102-104].

The use of IFN $\lambda$ family that induces a cellular antiviral and immunomodulatory response that is specific for the liver but has little or no activity in extrahepatic tissues as opposed to the standard IFN- $\alpha$ may more contribute a subsequent greater rate of OCI [104].

Another potential explanation for the failure to clear HCV-RNA from PBMC is a host-based resistance to the therapeutic actions of ribavirin (RBV). Ibarra et al. [105] have shown that cellular uptake of RBV into PBMCs decreases over time and may explain at least in part why PBMCs become a reservoir of $\mathrm{HCV}$ and potentially contributes to the development of treatment failure, disease recurrence, and in some cases the development of an OCI. In addition, Bartolomé et al. [49] have shown that HCV-infected B cells exhibit a IFN-resistant phenotype. These findings strongly suggest that the degree to which a viral infection of PBMC occurs contributes to the selection of distinct viral variants that persist in these cells and subsequently serve as the source of both late disease recurrences and OCI.

It has been recognized only recently that a balance exists between mobile antigens (viruses) and the antigenspecific $\mathrm{T}$ cells that govern the immunologic response or nonresponse to an infection agent. Specifically, Zinkernagel study experimental viral disease model noted that immunity to the virus as well as other intracellular infectious organisms is produced and maintained by a staged migration of the antigen (virus) and activated $\mathrm{T}$ cells and the outcome of this migration is governed by the cyo tokine, growth factors, and other interacting components that modulate viral and $\mathrm{T}$ cell behavior and the localization of specific features of lymphoid tissues. After an initial viral response, residual virus can become protected in nonlymphoid locations that are inaccessible to humoral and cellular effector mechanisms. Viruses in these locations are unrecognized until they migrate back to lymphoid tissues insufficient numbers to result in disease elimination (SVR) or disease reactivation (relapse) [106-109] Figure 3.

\section{Clinical Relevance}

Several small studies have described patients who have achieved an apparent SVR but continue to have HCVRNA detected in their peripheral blood mononuclear cells, lymphocytes, and macrophages utilizing more sensitive research assays [9-13, 110-114]. More importantly, the negative strand of HCV-RNA, consistent with viral replication, has been identified in the liver and peripheral blood mononuclear cells of patients having had an apparent SVR [115-117]. It needs to be pointed out that these highly sensitive reverse transcription polymerase chain reaction assays used in these investigational studies are not utilized clinically. Whether the virus detected with these techniques actually identifies replication-competent virus and 
therefore virus having clinical significance is not entirely clear.

Rahman et al. [118] have reported that a SVR to current IFN treatment regimens is durable in most patients, but not all and that late relapses can occur during long-term followup. Importantly, they reported that this finding occurs more often in patients with cirrhosis.

Similarly, Sood et al. [119] reported 100 patients, who achieved a SVR and were followed up for durations ranging from 6 months to 8 years. 8 of these 100 patients developed a late recurrence. The late relapses were more frequent in patients with cirrhosis (5/28 [18\%] versus $3 / 72$ [4\%] without cirrhosis; $P=0.037$ ). The data demonstrate that while a SVR is durable in most patients, some individuals particularly those with cirrhosis experience late relapses. Whether these late relapses are a result of OCI and whether the frequency of OCI in cirrhotics as suggested earlier is greater than in noncirrhotics and accounts for cases of OCI as well as cases of late relapses remain to be determined [119].

More recently, Rutter et al. [120] investigated the durability of a SVR in patients treated with peginterferon$\alpha 2 \mathrm{a} /$ ribavirin in combination with a direct acting antiviral agent. One hundred and three patients with chronic hepatitis C genotype 1 infection [f/m: 34/69; GT-1b: 67 GT-1a: 34, GT4: 2; mean age: 47.6 years $(45.5-49.7 ; 95 \% \mathrm{CI})]$ who achieved a SVR to triple therapy were followed. Two cases of a late relapse (2/103, 1.9\%; 95\% CI: 0.24-6.8) were observed. One of these two patients was cirrhotic. The relapses occurred 8 and 12 months after cessation of their antiviral therapy. Subsequent cloning sequence studies identified the genomic sequence in both patients as being identical to that of their original virus. In addition, resistance analysis revealed the absence of identifiable viral resistance to the therapeutic agents utilized in these two patients. These data support the conclusion that the relapses represented cases of clinically reactivated OCI rather than being a result of a de novo infection [120].

Gordon et al. [121] evaluated the long-term HCV-RNA outcomes following a defined SVR in 121 hemodialysis patients reported in 20 studies. The probability of remaining HCV-RNA negative was $86 \%$ (95\% confidence interval 77\% to $96 \%$ ) for patients followed for 48 months after their putative SVR. Fourteen relapsed, considering the data from Rutter et al., [120] it would appear that at least some of these 14 cases represented reactivation of an OCI in an immunosuppressed population.

Giannini et al. [122] evaluated a cohort of 231 chronic HCV patients who had at least 48 weeks of followup after achieving a SVR to PEG-IFN and ribavirin. The median duration of followup after the SVR time point was 164 weeks (3.2 years) and exceeded 5 years in $30 \%$ of the study population. All 231 patients underwent clinical, biochemical, and virological evaluations every 6 months during their followup. The original sustained virological response was maintained in 211 patients (91\%). HCV-RNA became positive in two patients $(<1 \%)$ within 1 year after the SVR, and in an additional 18 patients (8\%) HCV-RNA was transiently identified in the serum on at least one follow-up evaluation using a commercial assay with an HCV-RNA detection limit of $50 \mathrm{IU} / \mathrm{mL}$. These investigators reported that the clinical outcome of the 231 patients studied did not differ significantly between those with persistently negative and those who were transiently positive for HCV-RNA in serum following an earlier SVR. Nonetheless, as a result of their finding, these investigators recommended biannual HCV-RNA determinations in all patients after a putative SVR to identify cases with a late virological relapse presumably occurring as a result of an OCI [123].

It has been suggested that clearance of identifiable HCV from liver tissue and/or PBMC utilizing highly sensitive reverse transcription and nested polymerase chain reaction assays may be a better indicator of a long-term sustained response than the absence of HCV-RNA in serum or plasma $[56,115-117,124,125]$. Although the relevance of HCV-RNA detection in PBMCs alone, or in the liver in the absence of serum positivity, as well as other tissues is currently poorly understood, the ability of $\mathrm{HCV}$ to replicate in these extra hepatic cells, raises questions about the potential transmission risk to the liver from these sites and to other individuals as a result of blood exposure [123, 126-129]. Whether the incidence of OCI will increase with the recent shorter durations of treatment with DAA (6-24 weeks) and the revised shorter definition of a SVR of 8-12 weeks remains to be determined but is a concern. Relevant to this question, Dhaliwal and Nampoothiri [130] queried whether DAAs, which inhibit HCV by interrupting its life cycle without enhancing the individual's immune response, suppresses viral replication in the liver but not in extrahepatic sites which have reduced rates of viral replications as manifested by very much reduced viral load determinations and thereby are less susceptible to treatment with DAA [130]. Ultimately, longterm studies to confirm the durability of a SVR after the use of interferon-free DAA treatment regimens need to be determined.

\section{Prognosis of OCI}

Berasain et al. [131] reviewed 1075 consecutive liver biopsies from anti-HCV, HBsAg-negative patients with unexplained ALT elevations (defined as $>1.5$ upper limit of normal on two separate occasions). $27 \%$ of the cases were positive for either HBV-DNA or HCV-RNA utilizing highly sensitive techniques. The presence of a viral genome in the circulation, be it either HBV DNA or HCV-RNA, predicted clinical disease. Interestingly, the individuals with "cryptogenic" liver disease, who tested positive for either virus using the more sensitive research techniques, had a higher prevalence of cirrhosis than did those who tested negative for viruses [131].

In 100 patients with abnormal liver injury tests of unknown etiology, Castillo et al. [45] found detectable HCVRNA in the liver tissue of 57 cases which they identified as cases of OCI. Of these 57 patients, 20 (35\%) had histologic evidence of hepatic necroinflammation that occurred at a frequency significantly greater than that found in the 37 patients without intrahepatic HCV-RNA (14\%). In addition, the prevalence of cases with clinically significant fibrosis (F3 or F4) was significantly greater in those identified as having an OCI (17.5\%) than in those without an OCI (2.3\%) [45]. 


\section{The Future}

Yet to be fully established is whether current and more importantly the therapies that are in development are truly capable of eradicating HCV. The current trend to define a sustained viral response at 8,12 , or 24 weeks as opposed to 48 weeks may result in an increase in late recurrences of $\mathrm{HCV}$ as a result of incomplete eradication of $\mathrm{HCV}$ in extrahepatic tissues that serve as reservoirs of HCV and have reduced rates of viral replication and lower levels of virus and are the putative sites responsible for the development of OCI cases.

As mentioned above, Angulo et al. [98] reported that genomic HCV-RNA may be present in extrahepatic sites including peripheral blood mononuclear cells (PBMCs) in $79 \%$ of patients. They also have reported that the presence of HCV-RNA in PBMC is not linked with either the serum viral load, a particular HCV genotype, the age of the patient, the duration of infection, or presence or absence of cirrhosis. However, the presence of PBMC-associated HCV-RNA was been shown to be a strong predictor of a reduced likelihood of a SVR (OR 19.4) and was associated also with a reduced rate of rapid viral response (RVR) of $60 \%$ as compared to that occurring in individuals without detectable HCV-RNA in their PBMC.

Manns et al. [132] have asked why some HCV patients, who achieve an EOT response, relapse within the 24 weeks period after discontinuation of active therapy (the time period at which a SVR is defined) or more importantly even later. They reasoned that these late relapses, occurring more than 24 weeks after an EOT response might be explained by the use of less sensitive assays for HCV-RNA resulting in a false positive apparent SVR. They evaluated the data from several different centers in Europe and the USA utilizing various assays to quantify HCV-RNA in patients treated with either IFN-a-2-b or peg-IFN a-2b. They identified 6 definite late relapsers among 636 patients with a presumed prior SVR following treatment with IFN $\alpha-2 b$ and 3 definite late relapsers among 366 patients treated with PEG-IFN $\alpha-2 b$, during a 5 -year followup (0.9\%). A definite late relapse was defined as the finding of multiple sequential HCV-RNA tests that were positive. They also reported that there were 18 patients who received IFN $\alpha-2 \mathrm{~b}$ and had nondefinite relapse, and 15 patients who were treated with PEG-IFN $\alpha$-2b had a nondefinite relapse totaling 33 of 1002 cases (3.3\%).

These individuals had a single test in which HCV-RNA was detectable followed by subsequent tests in which HCVRNA was undetectable (possible intermittent OCI) [132].

Recently, more sensitive assays have been developed with significantly lower detection limits such as $15 \mathrm{IU} / \mathrm{mL}$ with the Roche COBAS TaqMan HCV test (Roche Diagnostics, North America, Indianapolis, IN) [133], $12 \mathrm{IU} / \mathrm{mL}$ with the Abbott Real Time HCV assay (Abbott, Chicago, IL) [134], and $10 \mathrm{IU} / \mathrm{mL}$ with the Bayer VERSANT Transcription-Mediated Amplification assay (Bayer Diagnostics, Berkley, CA) [135]. In addition, in situ hybridization $[19,136]$ is a useful tool for $\mathrm{HCV}$ detection in hepatic tissue while $\mathrm{HCV}$ core antigen testing [31] can be used in monitoring the HCV infection. Whether the use of these more sensitive assays would have affected the results reported by Manns et al. [132] is unknown.
Finally, current and future pharmacogenomic treatment approaches for HCV may be feasible with the incorporation of identifiable host (IFN $\lambda 3$ ) and viral E2 and NS3A polymorphisms genetic variants into predictive treatment algorithms along with the currently utilized factors identified as affecting viral clearance and outcome of antiviral therapies.

\section{Conclusions and Personal Perspective}

In summary, the following conclusions can be made:

(1) The evidence for the existence of the entity occult hepatitis $C$ is substantial and growing.

(2) OCI is recognized by the presence of HCV-RNA in either circulating blood mononuclear cells, the liver, or concentrated plasma triglyceride rich factions in the absence of detectable HCV-RNA in plasma.

(3) The longer the duration of followup after end of treatment (EOT) is, the greater the likelihood of identifying a case of occult $\mathrm{HCV}$ in previously treated individuals.

(4) Evidence is accumulating to suggest that cases of occult HCV occur in individuals with cryptogenic chronic liver disease consisting of both cirrhotic and noncirrhotic individuals.

(5) Individuals with immune mediated disorders such as membranous glomerulonephritis, cryoglobulinemia, and non-Hodgkin's lymphoma are increasingly being identified as having an occult $\mathrm{HCV}$ infection.

(6) Although the entity of OCI is becoming well recognized, its natural history is not yet fully defined.

(7) What is known, however, is that cirrhotic individuals with immune mediated disorders are more likely to harbor an occult HCV infection and that the pace of the liver disease in such individuals appears to be accelerated as compared to those without an OCI.

(8) Unique host and viral characteristics appear to contribute to the likelihood of an OCI.

These conclusions suggest the following speculations:

(a) Occult cases of HCV occur as a consequence of infection in unique nonhepatic immunologically protected sites or as a consequence of an infection with a HCV variant that is uniquely capable of infecting nonhepatic tissues.

(b) With the shorter duration of therapy with the new DAA and in the absence of interferon that has the potential to induce an immunologic attack directed at the putative "protected reservoirs" of HCV, concern for an increased prevalence of OCI in the future as a result of treatment with DAA represents a worrisome possibility.

\section{Conflict of Interests}

The authors declare that there is no conflict of interests regarding the publication of this paper. 


\section{References}

[1] J.-M. Pawlotsky, “Therapy of hepatitis C: from empiricism to eradication," Hepatology, vol. 43, no. 2, pp. S207-S220, 2006.

[2] B. Hajarizadeh, J. Grebely, and G. J. Dore, "Epidemiology and natural history of HCV infection," Nature Reviews Gastroenterology and Hepatology, vol. 10, no. 9, pp. 553-562, 2013.

[3] J.-M. Pawlotsky, "New hepatitis C therapies: the toolbox, strategies, and challenges," Gastroenterology, vol. 146, no. 5, pp. 11761192, 2014.

[4] E. R. Feeney and R. T. Chung, "Antiviral treatment of hepatitis C," The British Medical Journal, vol. 348, Article ID g3308, 2014.

[5] A. Slomski, "WHO issues guidelines on HCV amid drug cost controversy," The Journal of the American Medical Association, vol. 311, no. 22, pp. 2262-2263, 2014.

[6] R. Chou, D. Hartung, B. Rahman, N. Wasson, E. B. Cottrell, and R. Fu, "Comparative effectiveness of antiviral treatment for hepatitis C virus infection in adults: a systematic review," Annals of Internal Medicine, vol. 158, no. 2, pp. 114-123, 2013.

[7] M. Bourlière, A. Wendt, H. Fontaine, C. Hézode, S. Pol, and J. P. Bronowicki, "How to optimize HCV therapy in genotype 1 patients with cirrhosis," Liver International, vol. 33, no. 1, pp. 4655, 2013.

[8] L. Wei and A. S. F. Lok, "Impact of new hepatitis c treatments in different regions of the world," Gastroenterology, vol. 146, no. 5, pp. 1145-1150, 2014.

[9] T. N. Q. Pham, S. A. MacParland, P. M. Mulrooney, H. Cooksley, N. V. Naoumov, and T. I. Michalak, "Hepatitis C virus persistence after spontaneous or treatment-induced resolution of hepatitis C," Journal of Virology, vol. 78, no. 11, pp. 5867-5874, 2004.

[10] I. Castillo, M. Pardo, J. Bartolomé et al., "Occult hepatitis C virus infection in patients in whom the etiology of persistently abnormal results of liver function tests is unknown," Journal of Infectious Diseases, vol. 189, no. 1, pp. 7-14, 2004.

[11] L. de Marco, A. Gillio-Tos, V. Fiano et al., "Occult HCV infection: an unexpected finding in a population unselected for hepatic disease," PLoS ONE, vol. 4, no. 12, Article ID e8128, 2009.

[12] M.-W. Welker and S. Zeuzem, "Occult hepatitis C: how convincing are the current data?” Hepatology, vol. 49, no. 2, pp. 665-675, 2009.

[13] V. Carreño, J. Bartolomé, I. Castillo, and J. A. Quiroga, "New perspectives in occult hepatitis C virus infection," World Journal of Gastroenterology, vol. 18, no. 23, pp. 2887-2894, 2012.

[14] I. Castillo, E. Rodríguez-Iñigo, J. Bartolomé et al., "Hepatitis $\mathrm{C}$ virus replicates in peripheral blood mononuclear cells of patients with occult hepatitis C virus infection," Gut, vol. 54, no. 5, pp. 682-685, 2005.

[15] T. N. Q. Pham and T. I. Michalak, "Occult hepatitis C virus infection and its relevance in clinical practice," Journal of Clinical and Experimental Hepatology, vol. 1, no. 3, pp. 185-189, 2011.

[16] V. Carreño, M. Pardo, J. M. López-Alcorocho, E. RodríguezIñigo, J. Bartolomé, and I. Castillo, "Detection of hepatitis C virus (HCV) RNA in the liver of healthy, anti-HCV antibodypositive, serum HCV RNA-negative patients with normal alanine aminotransferase levels," Journal of Infectious Diseases, vol. 194, no. 1, pp. 53-60, 2006.

[17] F. Bernardin, L. Tobler, I. Walsh, J. D. Williams, M. Busch, and E. Delwart, "Clearance of hepatitis C virus RNA from the peripheral blood mononuclear cells of blood donors who spontaneously or therapeutically control their plasma viremia," Hepatology, vol. 47, no. 5, pp. 1446-1452, 2008.

[18] B. Pinarbasi, M. Bozaci, F. Akyuz et al., "The presence of HCVRNA in the peripheral blood mononuclear cells of the individuals with isolated anti HCV positivity: is HCV hiding out?” Journal of Hepatology, vol. 48, supplement 2, p. S222, 2008.

[19] T. N. Q. Pham, C. S. Coffin, and T. I. Michalak, "Occult hepatitis C virus infection: what does it mean?" Liver International, vol. 30, no. 4, pp. 502-511, 2010.

[20] G. H. Haydon, L. M. Jarvis, C. S. Blair et al., "Clinical significance of intrahepatic hepatitis $\mathrm{C}$ virus levels in patients with chronic HCV infection," Gut, vol. 42, no. 4, pp. 570-575, 1998.

[21] S. Barrett, N. Kieran, E. Ryan, J. C. O'Keane, and J. Crowe, "Intrahepatic hepatitis C viral RNA status of serum polymerase chain reaction-negative individuals with histological changes on liver biopsy," Hepatology, vol. 33, no. 6, pp. 1496-1502, 2001.

[22] Y. Sugiyasu, N. Yuki, T. Nagaoka et al., "Histological improvement of chronic liver disease after spontaneous serum hepatitis C virus clearance," Journal of Medical Virology, vol. 69, no. 1, pp. 41-49, 2003.

[23] M. Tomimatsu, H. Endou, H. Takahashi et al., "Negative strand of hepatitis $\mathrm{C}$ virus RNA in the liver of patients with chronic hepatitis C after interferon treatment," Journal of Gastroenterology and Hepatology, vol. 12, no. 9-10, pp. 629-632, 1997.

[24] T. N. Q. Pham, S. E. Mercer, and T. I. Michalak, "Chronic hepatitis $\mathrm{C}$ and persistent occult hepatitis $\mathrm{C}$ virus infection are characterized by distinct immune cell cytokine expression profiles," Journal of Viral Hepatitis, vol. 16, no. 8, pp. 547-556, 2009.

[25] T. N. Q. Pham, D. King, S. A. MacParland et al., "Hepatitis C virus replicates in the same immune cell subsets in chronic hepatitis C and occult infection," Gastroenterology, vol. 134, no. 3, pp. 812-822, 2008.

[26] M. Hoare, W. T. H. Gelson, S. M. Rushbrook et al., "Histological changes in HCV antibody-positive, HCV RNA-negative subjects suggest persistent virus infection," Hepatology, vol. 48, no. 6, pp. 1737-1745, 2008.

[27] T. N. Q. Pham, P. M. Mulrooney-Cousins, S. E. Mercer et al., "Antagonistic expression of hepatitis $\mathrm{C}$ virus and alpha interferon in lymphoid cells during persistent occult infection," Journal of Viral Hepatitis, vol. 14, no. 8, pp. 537-548, 2007.

[28] M. Radkowski, J. F. Gallegos-Orozco, J. Jablonska et al., "Persistence of hepatitis $\mathrm{C}$ virus in patients successfully treated for chronic hepatitis C," Hepatology, vol. 41, no. 1, pp. 106-114, 2005.

[29] I. Castillo, E. Rodríguez-Iñigo, J. M. López-Alcorocho, M. Pardo, J. Bartolomé, and V. Carreño, "Hepatitis C virus replicates in the liver of patients who have a sustained response to antiviral treatment," Clinical Infectious Diseases, vol. 43, no. 10, pp. 1277-1283, 2006.

[30] A. Ciancio, A. Smedile, C. Giordanino et al., "Long-term followup of previous hepatitis $\mathrm{C}$ virus positive nonresponders to interferon monotherapy successfully retreated with combination therapy: are they really cured?" American Journal of Gastroenterology, vol. 101, no. 8, pp. 1811-1816, 2006.

[31] J. A. Quiroga, S. Llorente, I. Castillo et al., "Virus-specific T-cell responses associated with hepatitis $\mathrm{C}$ virus $(\mathrm{HCV})$ persistence in the liver after apparent recovery from HCV infection," Journal of Medical Virology, vol. 78, no. 9, pp. 1190-1197, 2006.

[32] J. F. Gallegos-Orozco, J. Rakela, M. J. Rosati, H. E. Vargas, and V. Balan, "Persistence of hepatitis $\mathrm{C}$ virus in peripheral blood mononuclear cells of sustained viral responders to pegylated 
interferon and ribavirin therapy," Digestive Diseases and Sciences, vol. 53, no. 9, pp. 2564-2568, 2008.

[33] G. Di Liberto, A.-M. Roque-Afonso, R. Kara et al., "Clinical and therapeutic implications of hepatitis $\mathrm{C}$ virus compartmentalization," Gastroenterology, vol. 131, no. 1, pp. 76-84, 2006.

[34] N. Tsuda, N. Yuki, K. Mochizuki et al., "Long-term clinical and virological outcomes of chronic hepatitis $\mathrm{C}$ after successful interferon therapy," Journal of Medical Virology, vol. 74, no. 3, pp. 406-413, 2004.

[35] T. N. Q. Pham, S. A. MacParland, C. S. Coffin, S. S. Lee, F. R. Bursey, and T. I. Michalak, "Mitogen-induced upregulation of hepatitis C virus expression in human lymphoid cells," Journal of General Virology, vol. 86, no. 3, pp. 657-666, 2005.

[36] T. N. Q. Pham and T. I. Michalak, "Hepatitis C virus in peripheral blood mononuclear cells of individuals with isolated anti-hepatitis C virus antibody reactivity," Hepatology, vol. 48, no. 1, pp. 350-351, 2008.

[37] S. A. MacParland, T. N. Q. Pham, C. S. Guy, and T. I. Michalak, "Hepatitis $\mathrm{C}$ virus persisting after clinically apparent sustained virological response to antiviral therapy retains infectivity in vitro," Hepatology, vol. 49, no. 5, pp. 1431-1441, 2009.

[38] K. Katayama, J. Kumagai, Y. Komiya et al., "Titration of hepatitis $\mathrm{C}$ virus in chimpanzees for determining the copy number required for transmission," Intervirology, vol. 47, no. 1, pp. 5764, 2004.

[39] P. Halfon, M. Bourlière, D. Ouzan et al., "Occult hepatitis $\mathrm{C}$ virus infection revisited with ultrasensitive real-time PCR assay," Journal of Clinical Microbiology, vol. 46, no. 6, pp. 21062108, 2008.

[40] S. L. George, B. R. Bacon, E. M. Brunt, K. L. Mihindukulasuriya, J. Hoffman, and A. M. Di Bisceglie, "Clinical, virologic, histologic, and biochemical outcomes after successful HCV therapy: a 5-year follow-up of 150 patients," Hepatology, vol. 49, no. 3, pp. 729-738, 2009.

[41] S. Maylin, M. Martinot-Peignoux, R. Moucari et al., "Eradication of hepatitis $\mathrm{C}$ virus in patients successfully treated for chronic hepatitis C," Gastroenterology, vol. 135, no. 3, pp. 821829, 2008.

[42] S. Naga, S. H. T. Raghuraman, and J. R. B. Liang, "Minute levels of HCV RNA persist for an extended period of time after clinical recovery from hepatitis C but are ultimately cleared," in Proceedings of the 15th International Symposium on Hepatitis C Virus and Related Viruses, p. 66, San Antonio, Tex, USA, October 2008.

[43] P. Marcellin, N. Boyer, A. Gervais et al., "Long-term histologic improvement and loss of detectable intrahepatic HCV RNA in patients with chronic hepatitis $\mathrm{C}$ and sustained response to interferon- $\alpha$ therapy," Annals of Internal Medicine, vol. 127, no. 10, pp. 875-881, 1997.

[44] A.-M. Roque-Afonso, D. Ducoulombier, G. Di Liberto et al., "Compartmentalization of hepatitis $\mathrm{C}$ virus genotypes between plasma and peripheral blood mononuclear cells," Journal of Virology, vol. 79, no. 10, pp. 6349-6357, 2005.

[45] I. Castillo, J. Bartolomé, J. A. Quiroga, G. Barril, and V. Carreño, "Hepatitis $\mathrm{C}$ virus infection in the family setting of patients with occult hepatitis C," Journal of Medical Virology, vol. 81, no. 7, pp. 1198-1203, 2009.

[46] A. Y. Chen, M. Zeremski, R. Chauhan, I. M. Jacobson, A. H. Talal, and T. I. Michalak, "Persistence of hepatitis $\mathrm{C}$ virus during and after otherwise clinically successful treatment of chronic hepatitis $\mathrm{C}$ with standard pegylated interferon $\alpha-2 \mathrm{~b}$ and ribavirin therapy," PLoS ONE, vol. 8, no. 11, Article ID e80078, 2013.

[47] M. Inokuchi, T. Ito, H. Nozawa et al., "Lymphotropic hepatitis C virus has an interferon-resistant phenotype," Journal of Viral Hepatitis, vol. 19, no. 4, pp. 254-262, 2012.

[48] A. L. Zignego, C. Giannini, M. Monti, and L. Gragnani, "Hepatitis C virus lymphotropism: lessons from a decade of studies," Digestive and Liver Disease, vol. 39, supplement 1, pp. S38-S45, 2007.

[49] J. Bartolomé, J. M. López-Alcorocho, I. Castillo et al., "Ultracentrifugation of serum samples allows detection of hepatitis C virus RNA in patients with occult hepatitis C," Journal of Virology, vol. 81, no. 14, pp. 7710-7715, 2007.

[50] T. N. Q. Pham, C. S. Coffin, N. D. Churchill, S. J. Urbanski, S. S. Lee, and T. I. Michalak, "Hepatitis C virus persistence after sustained virological response to antiviral therapy in patients with or without past exposure to hepatitis B virus," Journal of Viral Hepatitis, vol. 19, no. 2, pp. 103-111, 2012.

[51] J. T. Blackard, N. Kemmer, and K. E. Sherman, "Extrahepatic replication of HCV: insights into clinical manifestations and biological consequences," Hepatology, vol. 44, no. 1, pp. 15-22, 2006.

[52] V. Falcón, N. Acosta-Rivero, M. Shibayama et al., "Evidences of hepatitis $\mathrm{C}$ virus replication in hepatocytes and peripheral blood mononuclear cells from patients negative for viral RNA in serum," American Journal of Infectious Diseases, vol. 1, pp. 3442, 2005.

[53] I. Castillo, J. Bartolomé, J. A. Quiroga, G. Barril, and V. Carreño, "Diagnosis of occult hepatitis $C$ without the need for a liver biopsy," Journal of Medical Virology, vol. 82, no. 9, pp. 1554-1559, 2010.

[54] A. G. Muazzam, S. Qureshi, A. Mansoor et al., "Occult HCV or delayed viral clearance from lymphocytes of Chronic HCV genotype 3 patients after interferon therapy," Genetic Vaccines and Therapy, vol. 9, no. 1, article 14, 2011.

[55] P. B. Sugden, B. Cameron, R. Bull, P. A. White, and A. R. Lloyd, "Occult infection with hepatitis $\mathrm{C}$ virus: friend or foe," Immunology and Cell Biology, vol. 90, no. 8, pp. 763-773, 2012.

[56] P. B. Sugden, T. N. Q. Pham, S. Ratnarajah et al., "Rare occurrence of occult hepatitis $\mathrm{C}$ virus in apparently uninfected injecting drug users: a two-centre, masked, case-control study," Journal of Viral Hepatitis, vol. 20, no. 10, pp. 725-728, 2013.

[57] F. Ansaldi, B. Bruzzone, S. Salmaso et al., "Different seroprevalence and molecular epidemiology patterns of hepatitis $C$ virus infection in Italy," Journal of Medical Virology, vol. 76, no. 3, pp. 327-332, 2005

[58] P. M. Kopko and P. V. Holland, "Universal leukocyte reduction," Current Opinion in Hematology, vol. 7, no. 6, pp. 397-401, 2000.

[59] L. De Marco, P. Manzini, M. Trevisan et al., "Prevalence and follow-up of occult HCV infection in an Italian population free of clinically detectable infectious liver disease," PLOS ONE, vol. 7, no. 8, Article ID e43541, 2012.

[60] G. Barril, I. Castillo, M. D. Arenas et al., "Occult hepatitis C virus infection among hemodialysis patients," Journal of the American Society of Nephrology, vol. 19, pp. 2248-2250, 2008.

[61] I. Castillo, J. Bartolomé, J. A. Quiroga, G. Barril, and V. Carreño, "Long-term virological follow up of patients with occult hepatitis C virus infection," Liver International, vol. 31, no. 10, pp. 1519-1524, 2011.

[62] F. Bokharaei-Salim, H. Keyvani, S. H. R. Monavari et al., "Occult hepatitis $\mathrm{C}$ virus infection in Iranian patients with cryptogenic 
liver disease," Journal of Medical Virology, vol. 83, no. 6, pp. 989995, 2011.

[63] H. Zaghloul and W. El-Sherbiny, "Detection of occult hepatitis $\mathrm{C}$ and hepatitis B virus infections from peripheral blood mononuclear cells," Immunological Investigations, vol. 39, no. 3, pp. 284-291, 2010.

[64] J. M. Cruzado, T. Casanovas-Taltavull, J. Torras, C. Baliellas, S. Gil-Vernet, and J. M. Grinyó, "Pretransplant interferon prevents hepatitis $\mathrm{C}$ virus-associated glomerulonephritis in renal allografts by HCV-RNA clearance," The American Journal of Transplantation, vol. 3, no. 3, pp. 357-360, 2003.

[65] S. Baid-Agrawal, R. Schindler, P. Reinke et al., "Prevalence of occult hepatitis $\mathrm{C}$ infection in chronic hemodialysis and kidney transplant patients," Journal of Hepatology, vol. 60, no. 5, pp. 928-933, 2014.

[66] P. Halfon, M. Martinot-Peignoux, and P. Cacoub, "The myth of occult hepatitis C infection," Hepatology, vol. 50, no. 5, article $1675,2009$.

[67] N. Coppola, M. Pisaturo, S. Guastafierro et al., "Absence of occult hepatitis $\mathrm{C}$ virus infection in patients under immunosupressive therapy for oncohematological diseases," Hepatology, vol. 54, no. 4, pp. 1487-1489, 2011.

[68] F. Nicot, N. Kamar, B. Mariamé, L. Rostaing, C. Pasquier, and J. Izopet, "No evidence of occult hepatitis C virus (HCV) infection in serum of HCV antibody-positive HCV RNA-negative kidney-transplant patients," Transplant International, vol. 23, no. 6, pp. 594-601, 2010.

[69] L. Richiardi, L. de Marco, A. Gillio-Tos et al., "Persistent infection by HCV and EBV in peripheral blood mononuclear cells and risk of non-Hodgkin's lymphoma," Cancer Epidemiology, vol. 34, no. 6, pp. 709-712, 2010.

[70] M. Casato, D. Lilli, G. Donato et al., "Occult hepatitis C virus infection in type II mixed cryoglobulinaemia," Journal of Viral Hepatitis, vol. 10, no. 6, pp. 455-459, 2003.

[71] C. Giannini, F. Giannelli, and A. L. Zignego, "Association between mixed cryogtobulinemia, translocation (14;18), and persistence of occult HCV lymphoid infection after treatment," Hepatology, vol. 43, no. 5, pp. 1166-1167, 2006.

[72] S. S. Youssef, A. S. Nasr, T. El Zanaty, R. S. El Rawi, and M. M. Mattar, "Prevalence of occult hepatitis C virus in Egyptian patients with chronic lymphoproliferative disorders," Hepatitis Research and Treatment, vol. 2012, Article ID 429784, 6 pages, 2012.

[73] M. Farahani, F. Bokharaei-Salim, M. Ghane, A. Basi, P. Meysami, and H. Keyvani, "Prevalence of occult hepatitis $\mathrm{C}$ virus infection in Iranian patients with lymphoproliferative disorders," Journal of Medical Virology, vol. 85, no. 2, pp. 235-240, 2013.

[74] I. Castillo, J. Martinez-Ara, T. Olea et al., "High prevalence of occult hepatitis $\mathrm{C}$ virus infection in patients with primary and secondary glomerular nephropathies," Kidney International, vol. 86, pp. 619-624, 2014.

[75] J. D. Scott and D. R. Gretch, "Molecular diagnostics of hepatitis $\mathrm{C}$ virus infection: a systematic review," Journal of the American Medical Association, vol. 297, no. 7, pp. 724-732, 2007.

[76] E. Kisiel, M. Radkowski, A. Pawelczyk et al., "Seronegative hepatitis $\mathrm{C}$ virus infection in patients with lymphoproliferative disorders," Journal of Viral Hepatitis, vol. 21, no. 6, pp. 424-429, 2014.

[77] J. A. Quiroga, S. Llorente, I. Castillo, E. Rodríguez-Iñigo, M. Pardo, and V. Carreño, "Cellular immune responses associated with occult hepatitis C virus infection of the liver," Journal of Virology, vol. 80, no. 22, pp. 10972-10979, 2006.

[78] V. Carreño, J. Bartolomé, I. Castillo, and J. A. Quiroga, “Occult hepatitis B virus and hepatitis C virus infections," Reviews in Medical Virology, vol. 18, no. 3, pp. 139-157, 2008.

[79] M. C. Roque-Cuéllar, B. Sánchez, J. R. García-Lozano et al., "Hepatitis $\mathrm{C}$ virus-specific cellular immune responses in sustained virological responders with viral persistence in peripheral blood mononuclear cells," Liver International, vol. 34, no. 6, pp. e80-e88, 2014.

[80] Y. S. Choi, J. E. Lee, S. J. Nam et al., "Two distinct functional patterns of hepatitis C Virus (HCV)-specific T cell responses in seronegative, aviremic patients," PLoS ONE, vol. 8, no. 4, Article ID e62319, 2013.

[81] H. R. Rosen, "Emerging concepts in immunity to hepatitis C virus infection," Journal of Clinical Investigation, vol. 123, no. 10, pp. 4121-4130, 2013.

[82] A. Grakoui, N. H. Shoukry, D. J. Woollard et al., "HCV persistence and immune evasion in the absence of memory T cell help," Science, vol. 302, no. 5645, pp. 659-662, 2003.

[83] N. H. Shoukry, A. Grakoui, M. Houghton et al., "Memory CD8 ${ }^{+}$ $\mathrm{T}$ cells are required for protection from persistent hepatitis $\mathrm{C}$ virus infection," Journal of Experimental Medicine, vol. 197, no. 12, pp. 1645-1655, 2003.

[84] A. Y. Kim, T. Kuntzen, J. Timm et al., "Spontaneous control of HCV is associated with expression of HLA-B ${ }^{\star} 57$ and preservation of targeted epitopes," Gastroenterology, vol. 140, no. 2, pp. 686-696, 2011.

[85] P. A. Knolle and R. Thimme, "Hepatic immune regulation and its involvement in viral hepatitis infection," Gastroenterology, vol. 146, no. 5, pp. 1193-1207, 2014.

[86] Y. Z. Gad, N. Mouas, A. Abdel-Aziz, N. Abousmra, and M. Elhadidy, "Distinct immunoregulatory cytokine pattern in Egyptian patients with occult Hepatitis C infection and unexplained persistently elevated liver transaminases," Asian Journal of Transfusion Science, vol. 6, no. 1, pp. 24-28, 2012.

[87] N. Mousa, W. Eldars, H. Eldegla et al., "Cytokine profiles and hepatic injury in occult hepatitis $\mathrm{C}$ versus chronic hepatitis $\mathrm{C}$ virus infection," International Journal of Immunopathology and Pharmacology, vol. 27, no. 1, pp. 87-96, 2014.

[88] J. K. Flynn, G. J. Dore, M. Hellard et al., "Maintenance of Th1 hepatitis $\mathrm{C}$ virus (HCV)-specific responses in individuals with acute $\mathrm{HCV}$ who achieve sustained virological clearance after treatment," Journal of Gastroenterology and Hepatology, vol. 28, no. 11, pp. 1770-1781, 2013.

[89] L. Zhang, C. Q. Hao, L. Miao, and X. Dou, "Role of Th1/Th2 cytokines in serum on the pathogenesis of chronic hepatitis C and the outcome of interferon therapy," Genetics and Molecular Research, vol. 13, no. 4, pp. 9747-9755, 2014.

[90] J. J. Feld, J. Grebely, G. V. Matthews et al., "Plasma interferongamma-inducible protein-10 levels are associated with early, but not sustained virological response during treatment of acute or early chronic HCV infection," PLoS ONE, vol. 8, no. 11, Article ID e80003, 2013.

[91] V. Natarajan, S. Kottilil, A. Hazen et al., "HCV in peripheral blood mononuclear cells are predominantly carried on the surface of cells in HIV/HCV co-infected individuals," Journal of Medical Virology, vol. 82, no. 12, pp. 2032-2037, 2010.

[92] K. Fujiwara, R. D. Allison, R. Y. Wang et al., "Investigation of residual hepatitis C virus in presumed recovered subjects," Hepatology, vol. 57, no. 2, pp. 483-491, 2013. 
[93] T. Laskus, M. Radkowski, A. Piasek et al., "Hepatitis C virus in lymphoid cells of patients coinfected with human immunodeficiency virus type 1 : evidence of active replication in monocytes/macrophages and lymphocytes," Journal of Infectious Diseases, vol. 181, no. 2, pp. 442-448, 2000.

[94] S. Ramirez, S. Perez-Del-Pulgar, J. A. Carrion et al., "Hepatitis C virus compartmentalization and infection recurrence after liver transplantation," American Journal of Transplantation, vol. 9, no. 7, pp. 1591-1601, 2009.

[95] S. V. Kotenko, "IFN- $\lambda$ s," Current Opinion in Immunology, vol. 23, no. 5, pp. 583-590, 2011.

[96] J. Vera-Otarola, M. I. Barría, U. León et al., "Hepatitis C virus quasispecies in plasma and peripheral blood mononuclear cells of treatment naïve chronically infected patients," Journal of Viral Hepatitis, vol. 16, no. 9, pp. 633-643, 2009.

[97] P. K. Chandra, L. Bao, K. Song et al., "HCV infection selectively impairs type i but not type III IFN signaling," American Journal of Pathology, vol. 184, no. 1, pp. 214-229, 2014.

[98] J. Angulo, K. Pino, C. Pavez et al., "Genetic variations in host IL28B links to the detection of peripheral blood mononuclear cells-associated hepatitis $\mathrm{C}$ virus RNA in chronically infected patients," Journal of Viral Hepatitis, vol. 20, no. 4, pp. 263-272, 2013.

[99] M. T. Dill, F. H. T. Duong, J. E. Vogt et al., "Interferoninduced gene expression is a stronger predictor of treatment response than IL28B genotype in patients with hepatitis C," Gastroenterology, vol. 140, no. 3, pp. 1021-1031, 2011.

[100] S. Marukian, L. Andrus, T. P. Sheahan et al., "Hepatitis C virus induces interferon-lambda and interferon-stimulated genes in primary liver cultures," Hepatology, vol. 54, no. 6, pp. 1913-1923, 2011.

[101] O. Bauhofer, A. Ruggieri, B. Schmid, P. Schirmacher, and R. Bartenschlager, "Persistence of HCV in quiescent hepatic cells under conditions of an interferon-induced antiviral response," Gastroenterology, vol. 143, no. 2, pp. 429-438, 2012.

[102] A. Amanzada, A. Goralczyk, F. Moriconi et al., "Ultra-rapid virological response, young age, low $\gamma$-GT/ALT-ratio, and absence of steatosis identify a subgroup of HCV genotype 3 patients who achieve SVR with IFN- $\alpha_{2 \mathrm{a}}$ monotherapy," Digestive Diseases and Sciences, vol. 56, no. 11, pp. 3296-3304, 2011.

[103] S. S. Youssef, A. M. Abd El-Aal, A. Saad, M. Hassan Omran, T. El Zanaty, and S. M. Seif, "Impact of IL12B gene rs 3212227 polymorphism on fibrosis, liver inflammation, and response to treatment in genotype 4 Egyptian hepatitis C patients," Disease Markers, vol. 35, no. 5, pp. 431-437, 2013.

[104] F. Bellanti, G. Vendemiale, E. Altomare, and G. Serviddio, "The impact of interferon lambda 3 gene polymorphism on natural course and treatment of hepatitis C," Clinical and Developmental Immunology, vol. 2012, Article ID 849373, 9 pages, 2012.

[105] K. D. Ibarra, M. K. Jain, and J. K. Pfeiffer, "Host-based ribavirin resistance influences hepatitis $\mathrm{C}$ virus replication and treatment response," Journal of Virology, vol. 85, no. 14, pp. 7273-7283, 2011.

[106] R. M. Zinkernagel, "Immunology taught by viruses," Science, vol. 271, no. 5246, pp. 173-178, 1996.

[107] R. M. Zinkernagel, M. F. Bachmann, T. M. Kündig, S. Oehen, H. Pirchet, and H. Hengartner, "On immunological memory," Annual Review of Immunology, vol. 14, no. 1, pp. 333-367, 1996.

[108] R. M. Zinkernagel, S. Ehl, P. Aichele, S. Oehen, T. Kündig, and $\mathrm{H}$. Hengartner, "Antigen localisation regulates immune responses in a dose- and time-dependent fashion: a geographical view of immune reactivity," Immunological Reviews, vol. 156, pp. 199-209, 1997.

[109] T. E. Starzl and R. M. Zinkernagel, "Antigen localization and migration in immunity and tolerance," The New England Journal of Medicine, vol. 339, no. 26, pp. 1905-1913, 1998.

[110] J. T. Blackard, L. Smeaton, Y. Hiasa et al., "Detection of hepatitis $\mathrm{C}$ virus $(\mathrm{HCV})$ in serum and peripheral-blood mononuclear cells from HCV-monoinfected and HIV/HCV-coinfected persons," Journal of Infectious Diseases, vol. 192, no. 2, pp. 258-265, 2005.

[111] P. Baré, "Hepatitis C virus and peripheral blood mononuclear cell reservoirs Patricia Baré," World Journal of Hepatology, vol. 1, no. 1, p. 67, 2009.

[112] M. C. Roque-Cuéllar, B. Sánchez, J. R. García-Lozano, J. M. Praena-Fernández, A. Núñez-Roldán, and J. Aguilar-Reina, "Cellular immune responses and occult infection in seronegative heterosexual partners of chronic hepatitis C patients," Journal of Viral Hepatitis, vol. 18, no. 10, pp. e541-e549, 2011.

[113] H. Keyvani, F. Bokharaei-Salim, S. H. Monavari et al., "Occult hepatitis $\mathrm{C}$ virus infection in candidates for liver transplant with cryptogenic cirrhosis," Hepatitis Monthly, vol. 13, no. 8, Article ID el1290, 2013.

[114] P. Dzekova Vidimliski, I. Nikolov, N. Matevska Geshkovska, A. Dimovski, L. Rostaing, and A. Sikole, "Occult hepatitis C virus infection: still remains a controversy," Journal of Medical Virology, vol. 86, no. 9, pp. 1491-1498, 2014.

[115] L. Gatserelia, L. Sharvadze, M. Karchava et al., "Occurrence of occult HCV infection among HIV infected patients in Georgia," Georgian Medical News, no. 226, pp. 37-41, 2014.

[116] T. Laskus, E. A. Operskalski, M. Radkowski et al., "Negativestrand hepatitis $\mathrm{C}$ virus (HCV) RNA in peripheral blood mononuclear cells from anti-HCV-positive/HIV-infected women," The Journal of Infectious Diseases, vol. 195, no. 1, pp. 124-133, 2007.

[117] A. Pawełczyk, N. Kubisa, J. Jabłońska et al., "Detection of hepatitis $\mathrm{C}$ virus (HCV) negative strand RNA and NS3 protein in peripheral blood mononuclear cells (PBMC): $\mathrm{CD}^{+}, \mathrm{CD}^{+} 4^{+}$ and CD19+," Virology Journal, vol. 10, article 46, 2013.

[118] M. Z. Rahman, D. S. Ahmed, H. Masud et al., "Sustained virological response after treatment in patients with chronic hepatitis C infection-a five year follow up," Bangladesh Medical Research Council Bulletin, vol. 39, no. 1, pp. 11-13, 2013.

[119] A. Sood, V. Midha, V. Mehta et al., "How sustained is sustained viral response in patients with hepatitis $\mathrm{C}$ virus infection?" Indian Journal of Gastroenterology, vol. 29, no. 3, pp. 112-115, 2010.

[120] K. Rutter, H. Hofer, S. Beinhardt et al., "Durability of SVR in chronic hepatitis $\mathrm{C}$ patients treated with peginterferon$\alpha 2 \mathrm{a} /$ ribavirin in combination with a direct-acting anti-viral," Alimentary Pharmacology and Therapeutics, vol. 38, no. 2, pp. 118-123, 2013.

[121] C. E. Gordon, K. Uhlig, C. H. Schmid, A. S. Levey, and J. B. Wong, "Long-term viral negativity after Interferon for chronic hepatitis C virus infection in hemodialysis," Clinical Journal of the American Society of Nephrology, vol. 6, no. 9, pp. 2226-2234, 2011.

[122] E. G. Giannini, M. Basso, V. Savarino, and A. Picciotto, "Sustained virological response to pegylated interferon and ribavirin is maintained during longterm follow up of chronic hepatitis $\mathrm{C}$ patients," Alimentary Pharmacology \& Therapeutics, vol. 31, pp. 502-508, 2010. 
[123] F. M. Cortés-Mancera, J. C. Restrepo, G. Osorio, S. Hoyos, G. Correa, and M. C. Navas, "Occult hepatitis C virus infection in a re-transplanted patient with liver failure of unknown etiology," Revista Colombiana de Gastroenterologia, vol. 25, no. 1, pp. 7685, 2010.

[124] J. A. Quiroga, I. Castillo, M. Pardo, E. Rodríguez-Iñigo, and V. Carreño, "Combined hepatitis $\mathrm{C}$ virus (HCV) antigen-antibody detection assay does not improve diagnosis for seronegative individuals with occult HCV infection," Journal of Clinical Microbiology, vol. 44, no. 12, pp. 4559-4560, 2006.

[125] M. Comar, G. Dal Molin, P. D’Agaro, S. L. Crocè, C. Tiribelli, and C. Campello, "HBV, HCV, and TTV detection by in situ polymerase chain reaction could reveal occult infection in hepatocellular carcinoma: comparison with blood markers," Journal of Clinical Pathology, vol. 59, no. 5, pp. 526-529, 2006.

[126] J. A. Quiroga, S. Llorente, I. Castillo et al., “Tracking intrafamilial spread of serologically silent occult HCV infection through humoral and cellular HCV-specific responses," Journal of Hepatology, vol. 50, supplement 1, p. S149, 2009.

[127] F. Fabrizi and P. Martin, "Occult hepatitis C virus infection in hemodialysis," Journal of the American Society of Nephrology, vol. 19, no. 12, pp. 2248-2250, 2008.

[128] H. Lerat and F. B. Hollinger, "Hepatitis C virus (HCV) occult infection or occult HCV RNA detection?" Journal of Infectious Diseases, vol. 189, no. 1, pp. 3-6, 2004.

[129] J. W. Ward, "The hidden epidemic of hepatitis $C$ virus infection in the United States: occult transmission and burden of disease," Topics in Antiviral Medicine, vol. 21, no. 1, pp. 15-19, 2013.

[130] H. S. Dhaliwal and R. V. Nampoothiri, "Daclatasvir plus sofosbuvir for HCV infection," The New England Journal of Medicine, vol. 370, no. 16, pp. 1560-1561, 2014.

[131] C. Berasain, M. Betés, A. Panizo et al., "Pathological and virological findings in patients with persistent hypertransaminasaemia of unknown aetiology," Gut, vol. 47, no. 3, pp. 429-435, 2000.

[132] M. P. Manns, P. J. Pockros, G. Norkrans et al., "Long-term clearance of hepatitis $\mathrm{C}$ virus following interferon $\alpha-2 \mathrm{~b}$ or peginterferon $\alpha-2 \mathrm{~b}$, alone or in combination with ribavirin," Journal of Viral Hepatitis, vol. 20, no. 8, pp. 524-529, 2013.

[133] Roche Diagnostics, COBAS AmpliPrep/COBAS TaqMan HCV Test, http://www.roche-diagnostics.us.

[134] Abbott Molecular, http://www.abbottmolecular.com/.

[135] BayerMaterialScience, 2014, http://www.bayermaterialsciencenafta.com/.

[136] G. Li, K. Li, A. S. Lea et al., "In situ hybridization for the detection of hepatitis C virus RNA in human liver tissue," Journal of Viral Hepatitis, vol. 20, no. 3, pp. 183-192, 2013. 


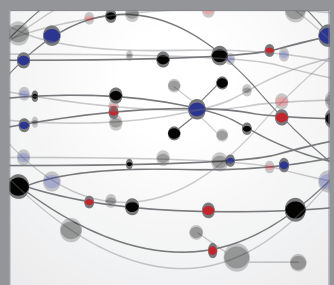

The Scientific World Journal
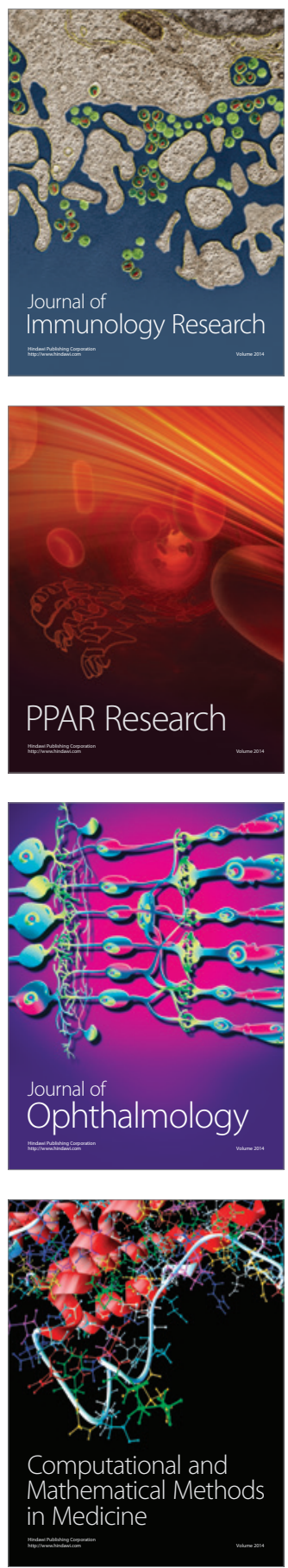

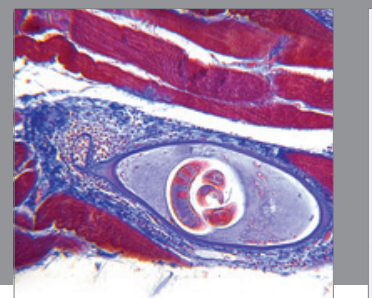

Gastroenterology

Research and Practice
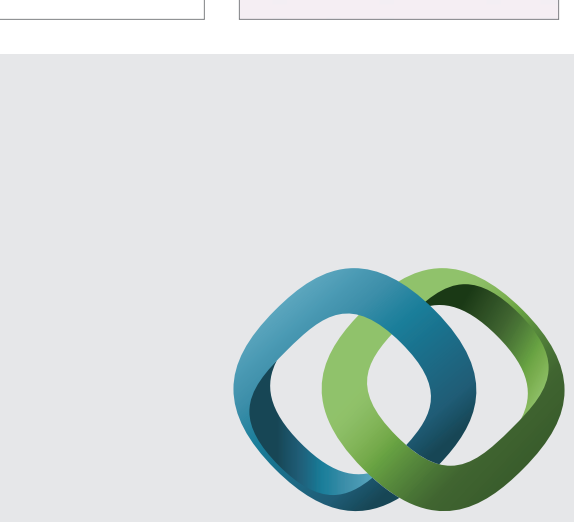

\section{Hindawi}

Submit your manuscripts at

http://www.hindawi.com
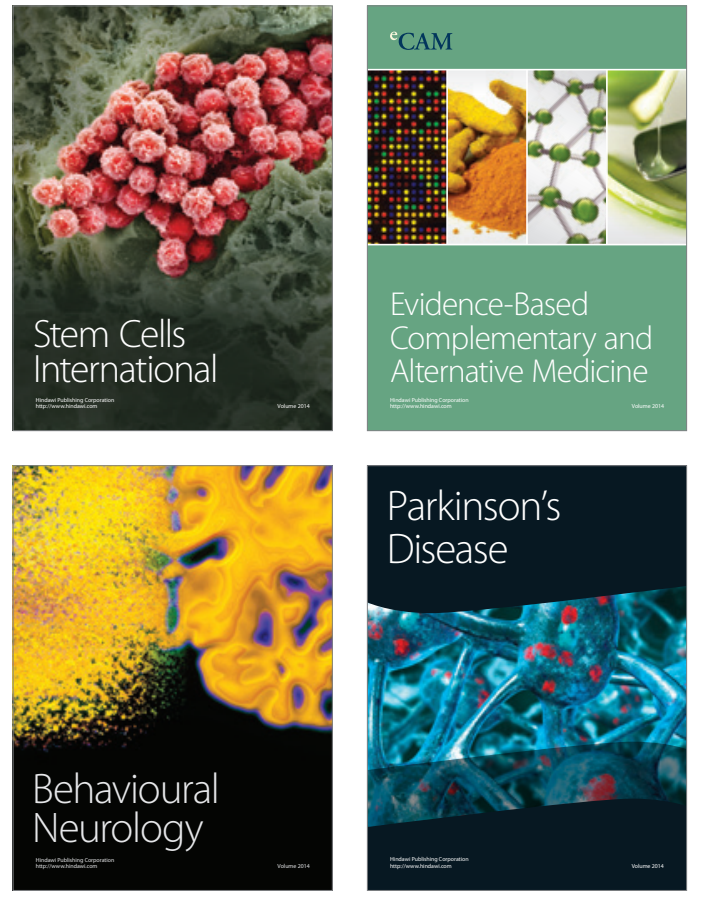
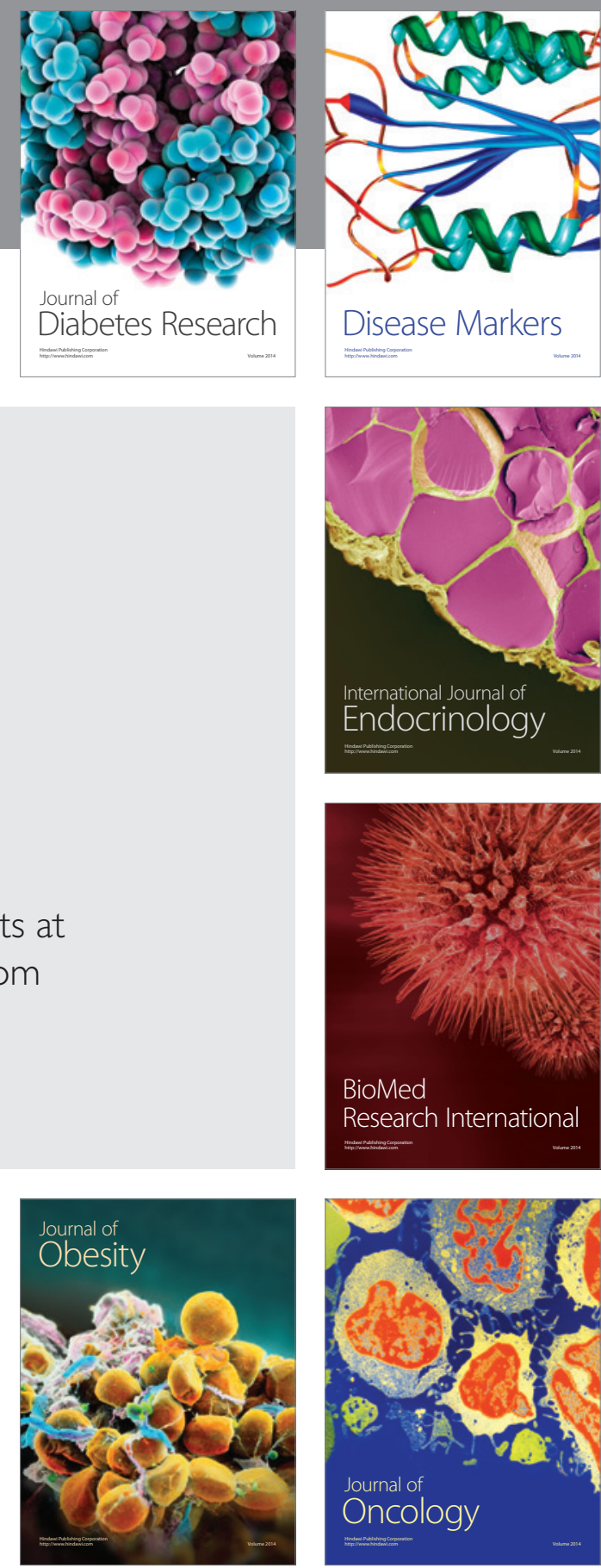

Disease Markers
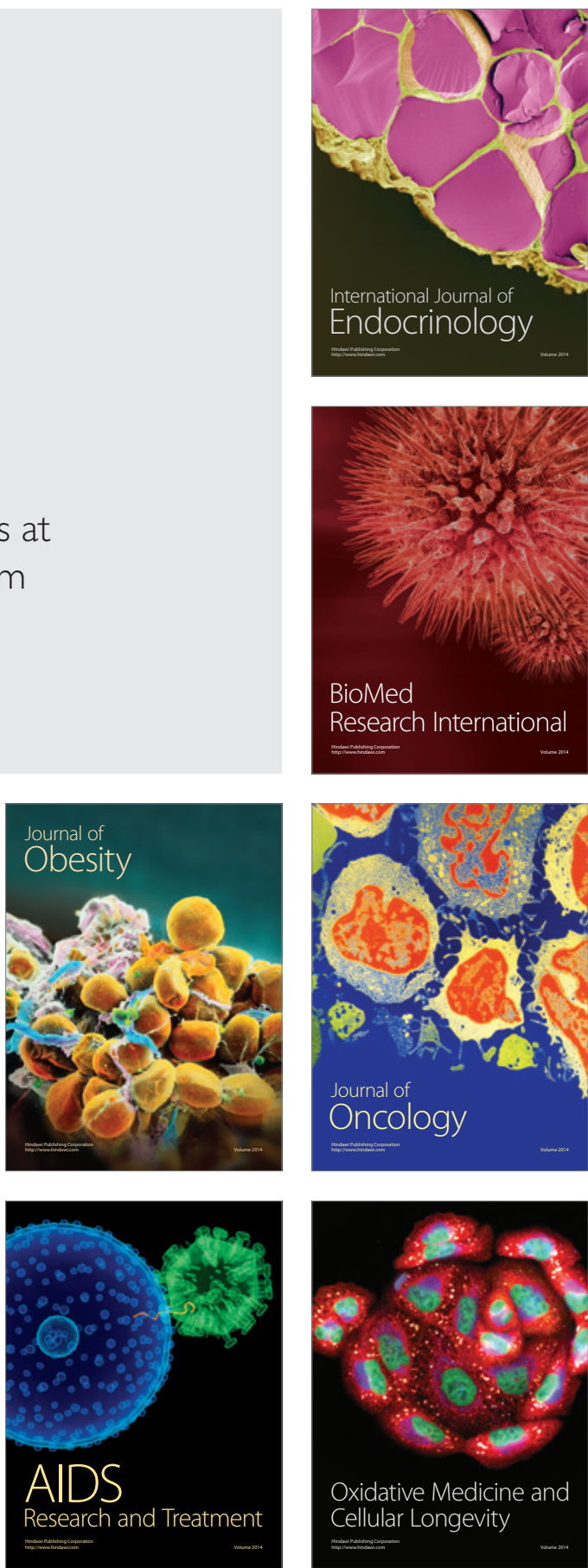